\title{
KOLEKTIVITAS SUKSESKAN PEMILIHAN UMUM 2014
}

\section{Oleh: M. Jamil ${ }^{1}$}

Kolektivitas merupakan sikap yang tertanam dalam diri pribadi seseorang yang memiliki rasa kebersamaan, keterpaduan, serta tindak kebersamaan dalam melalukan segala sesuatu, baik segala sesuatu itu bernilai positif maupun bernilai negatif, namun maksud dalam tulisan kali ini yaitu mengandung pentingnya membangun suatu kebersaan agar tercapai suatu tujuan yang baik atau suatu tujuan yang bernilai positif.

Pada dasarnya manusia adalah makhluk sosial yang tidak bisa hidup sendiri dalam berkehidupan di suatu masyarakat, bangsa dan Negara, manusia tersebut pasti memerlukan suatu kebersamaan atau bantuan dari seseorang untuk melakukan sesuatu yang ingin dia capai, walau ada juga sebagian yang bisa dilakukan sendiri namun dalam suatu kehidupan pasti lebih banyak suatu kebutuhan untuk memenuhi tuntutan hidupnya memerlukan bantuan dari orang lain.

Undang-Undang Nomor 8 Tahun 2012 tentang Pemilihan Umum Anggota Dewan Perwakilan Rakyat, Dewan Perwakilan Daerah, dan Dewan Perwakilan Rakyat Daerah, pada Pasal 1 Ayat 1 menyebutkan "Pemilihan Umum (Pemilu) adalah sarana pelaksanaan kedaulatan rakyat yang dilaksanakan secara langsung, umum, bebas, rahasia, jujur, dan adil dalam Negara Kesatuan Republik Indonesia berdasarkan Pancasila dan Undang-Undang Dasar Negara Republik Indonesia Tahun 1945".

Pemilihan Umum dilaksanakan secara langsung, umum, bebas, rahasia, jujur, dan adil setiap lima tahun sekali, seperti yang diamanatkan oleh Undang-

1 Ketua Umum Pusat Studi Mahasiswa Pascasarjana (PUSMAJA) Mbojo-Yogyakarta Periode 2015-2017 | | Ketua II Bagian Eksternal Dewan Pimpinan Cabang Perhimpunan Mahasiswa Hukum Indonesia Daerah Istimewa Yogyakarta (DPC PERMAHI DIY) Periode 20122014 | Email: jamilncera@gmail.com | FB/Youtube/IG/Twitter: @MJAMILSH | Website: http://www.mjamil.my.id. 
Undang Dasar Negara Republik Indonesia Tahun 1945 pada pasal 22E Ayat 1. Kita tahu bersama bahwasannya masa kepemimpinan Susilo Bambang Yudoyono (SBY) akan berakhir tahun ini, dan dalam beberapa minggu lagi pesta Pemilu 2014 akan menghampiri kita. Dalam setiap pemilu, baik Pemilu Kepala Desa di tingkat Desa, Pemilu Bupati/Walikota ditingkat Kabupaten/Kota, Pemilu Gubernur ditingkat Provinsi, Pemilu Legislatif di tingkat DPRD Kabupaten, DPRD Provinsi, DPR RI, DPD RI, maupun Pemilu Presiden pasti sarat akan konflik-konflik atau suatu permasalahan. Oleh karena itu, kewajiban bagi kita semua untuk mensukseskan Pemilu tersebut agar tidak terjadi atau meminimalisir konflik-konflik atau suatu permasalahan tersebut.

Pemilihan anggota Dewan Perwakilan Rakyat, Dewan Perwakilan Daerah, dan Dewan Perwakilan Rakyat Daerah merupakan alat sebagai sarana perwujudan kedaulatan rakyat untuk menghasilkan wakil rakyat yang aspiratif, berkualitas, dan bertanggung jawab berdasarkan Pancasila dan Undang-Undang Dasar Negara Republik Indonesia Tahun 1945. Oleh karenanya, kita sebagai warga negara yang baik, harus turut andil untuk mensukseskan Pemilu tersebut, agar apa yang dicitacitakan bersama yakni terpilihnya wakil rakyat yang aspiratif, berkualitas, dan bertanggung jawab.

Mensukseskan Pemilu 2014 adalah cita-cita kita bersama, cita-cita dari semua lapisan, cita-cita para Calon Legislatif (calon anggota Dewan), cita-cita Pemerintah, cita-cita Penegak Hukum, serta cita-cita masyarakat indonesia, untuk menggapai cita-cita tersebut kita harus berperan serta dan berjuang bersama-sama.

\section{Peran Pemerintah}

Untuk memperlancar berjalannya Pemilihan Umum, Pemerintah telah membentuk Komisi Pemilihan Umum yang bersifat independent. Seperti yang terpartri dalam Undang-Undang Dasar Republik Indonesia pada Pasal 22E ayat (5) berbunyi "Pemilihan umum diselenggarakan oleh suatu komisi pemilihan umum yang bersifat nasional, tetap, dan mandiri”.

Adapun tugas dan wewenang Komisi Pemilihan Umum yang diamanahkan oleh Pasal 2 Keputusan Presiden Nomor 16 Tahun 1999 tentang Pembentukan 
Komisi Pemilihan Umum dan Penetapan Organisasi dan Tata Kerja Sekretatiat Umum Komisi Pemilihan Umum, adalah sebagai berikut: (1) merencanakan dan mempersiapkan pemilihan umum; (2) menerima, meneliti dan menetapkan partaipartai politik yang berhak sebagai peserta Pemilihan Umum; (3) membentuk Panitia Pemilihan Indonesia yang selanjutnya disebut PPI dan mengkoordinasikan kegiatan Pemilihan Umum mulai dari tingkat pusat sampai di Tempat Pemungutan Suara yang selanjutnya disebut TPS; (4) menetapkan jumlah kursi anggota DPR, DPRD I dan DPRD II untuk setiap daerah pemilihan; (5) menetapkan keseluruhan hasil pemilihan umum disemua daerah pemilihan untuk DPR, DPRD I dan DPRD II; (6) mengumpulkan dan mensistemasikan bahanbahan serta data hasil pemilihan umum; (7) memimpin tahapan pemilihan umum. Dengan tugas dan wewenang yang diberikan undang-undang, semoga Komisi Pemilihan Umum menggunakan sebaik-baiknya, agar tercipta Pemilu 2014 yang sukses dambaan bersama.

\section{Peran Penegak Hukum}

Penegak Hukum yang berperan aktif menangani permasalahan pemeliharaan keamanan dan ketertiban masyarakat saat Pemilu adalah Kepolisian Republik Indonesia. Mengingat amandemen kedua Undang-undang Dasar Tahun 1945 pasal 30 Ayat (4) menyebutkan bahwasannya "Kepolisian Negara Republik Indonesia sebagai alat negara yang menjaga keamanan dan ketertiban masyarakat bertugas melindungi, mengayomi, melayani masyarakat, serta menegakkan hukum" demi untuk pemeliharaan keamanan dalam negeri melalui upaya penyelenggaraan fungsi kepolisian yang meliputi pemeliharaan keamanan dan ketertiban masyarakat, penegakan hukum, perlindungan, pengayoman, dan pelayanan kepada masyarakat dilakukan oleh Kepolisian Negara Republik Indonesia selaku alat negara yang dibantu oleh masyarakat dengan menjunjung tinggi hak asasi manusia.

Perkembangan kemajuan masyarakat yang cukup pesat, seiring dengan merebaknya fenomena supremasi hukum, hak asasi manusia, globalisasi, demokratisasi, desentralisasi, transparansi, dan akuntabilitas, telah melahirkan 


\section{Terbit 10 Maret 2014}

"Kolektivitas Sukseskan Pemilihan Umum 2014"

berbagai paradigma baru dalam melihat tujuan, tugas, fungsi, wewenang dan tanggung jawab Kepolisian Negara Republik Indonesia yang selanjutnya menyebabkan pula tumbuhnya berbagai tuntutan dan harapan masyarakat terhadap pelaksanaan tugas Kepolisian Negara Republik Indonesia yang makin meningkat dan lebih berorientasi kepada masyarakat yang dilayaninya.

Peran Kepolisian sangat besar karena pihak Kepolisian berperan aktif untuk keamanan dan ketertiban mulai sebelum dilakukan pesta demokrasi sampai saat pelaksanaan demokrasi (Pemilu), agar tidak terjadi hal-hal yang tidak diinginkan sehingga meresahkan masyarakat.

\section{Peran Para Calon Anggota Dewan}

Calon anggota Dewan yang dimaksud disini adalah calon Anggota Dewan Perwakilan Rakyat Daerah Kabupaten/Kota diwilayah Kabupaten/Kota, calon Anggota Dewan Perwakilan Rakyat Daerah Provinsi di wilayah Provinsi, Dewan Perwakilan Daerah Republik Indonesia, dan Dewan Perwakilan Rakyat Republik Indonesia di tingkat Nasional. Calon Anggota Dewan Perwakilan Rakyat Daerah Kabupaten/Kota di wilayah Kabupaten, mereka akan berjuang dengan keras untuk mendapatkan suara di daerah pemilihannya, tentu dalam menjaring suara dilakukan dengan cara dan taktik yang tidak bertentangan dengan etik dan tingkahlaku masyarakat serta undang-undang. Calon Anggota Dewan Perwakilan Rakyat Daerah Provinsi di tingkat wilayah Provinsi, mereka akan berjuang dengan keras untuk mendapatkan suara di daerah pemilihannya, tentu dalam menjaring suara dilakukan dengan cara dan taktik yang tidak bertentangan dengan etik dan tingkahlaku masyarakat serta undang-undang. Begitu juga dengan Calon Anggota Dewan Perwakilan Daerah Republik Indonesia dan Calon Anggota Dewan Perwakilan Rakyat Republik Indonesia. Ketika saat Pemilu berlangsung dan saat hasilnya telah diketahui, maka Anggota Dewan yang terpilih dalam merayakan kemenangannya tidak dilakukan dengan berlebihan yang mungkin dengan cara itu menyebabkan para calon yang tidak menang merasa tersinggung dan yang lainnya. Begitu juga sebaliknya, apabila telah diketahui hasilnya tidak sesuai dengan harapan (kemenangan), maka ia juga menerima dengan hati yang 
lapang akan kekalahan yang dialaminya, kalaupun ada kejanggalan dalam proses pelaksanaan Pemilu, maka dilalui dengan jalur yang diatur oleh undang-undang. Dalam hal adanya suatu sengketa Pemilu, yakni perselisihan tentang hasil pemilihan umum, maka akan diadili di Lembaga Mahkamah Konstitusi, seperti amanah Undang-Undang Dasar Republik Indonesia pada Pasal 24C Ayat (1) berbunyi "Mahkamah Konstitusi berwenang mengadili pada tingkat pertama dan terakhir yang putusannya bersifat final untuk menguji undang-undang terhadap Undang-Undang Dasar, memutus sengketa kewenangan lembaga negara yang kewenangannya diberikan oleh Undang-Undang Dasar, memutus pembubaran partai politik, dan memutus perselisihan tentang hasil pemilihan umum".

\section{Peran Masyarakat Umum}

Hidup dan kehidupan dalam bermasyarakat syarat akan nilai kebersamaan, itulah sejatinya hidup dalam bermasyarakat yang telah menjadi tradisi dari masa ke masa sejak ribuan tahun silam, yang mana kebersamaan tersebut dibuktikan dengan adanya nilai-nilai yang tertanam dalam pribadi-pribadi masyarakat, diantaranya seperti gotong royong, musyawarah mufakat, dan lain sebagainya. Sikap kebersamaan (kolektifitas) tersebut juga harus terpartri dalam mensukseskan Pemilu, karena beberapa minggu lagi kita dihadapkan dengan Pemilu 2014, maka semua lapisan masyarakat harus berperan aktif untuk mensukseskannya, yang bisa dilakukan masyarakat adalah ketika para calon Legislatif turun di masyarakat mengubarkan janji-janji manisnya, maka masyarakat harus jeli dan cerdas dalam menyikapinya, jangan sampai orang yang di pilih tidak mewakili aspirasi-aspirasi masyarakat hingga sebaliknya yang terjadi kelak bila telah terpilih jadi Anggota Dewan yakni menyimpangi dari tanggungjawab yang harus Anggota Dewan lakukan. Bila mana dalam lapangan ada Calon Legislatif yang menyuap masyarakat, yakinlah dan percayalah, orangorang semacam itu tidak akan mau melaksanakan apa yang menjadi kewajibannya bila telah menjadi Anggota Dewan. Karena ketika telah menjadi Anggota Dewan yang paling pertama dia pikirkan adalah, bagaimana caranya untuk mengembalikan uang-uang yang telah mereka keluarkan, dan dengan 
kewenangannya yang besar, mereka bisa dengan leluasa memanfaatkannya untuk menggunakan dana agar uang yang dia keluarkan semasa kampanye cepat kembali dan bahkan mengambil sebanyak-banyaknya untuk memperkaya dirinya dan keluarganya.

\section{Peran Pemuda/Mahasiswa}

Pemuda/Mahasiswa merupakan agen pengontrol (agent of control) dan agen perubahan (agent of change), yang mana ditangan mahasiswa bisa membuat atau menciptakan suatu perubahan dalam suatu lingkup masyarakat, bangsa, Negara, bahkan dunia, karena dengan sifat dan karakter mahasiswa yang sejatinya masih murni dari kendali atau pengaruh siapapun (independent), dengan kemurnian hati dan pikiran seorang mahasiswa bisa merangkul dari aspirasi semua kalangan, lebih-lebih untuk kepentingan masyarakat menengah kebawan. Seperti selogan yang pernah digembar-gemborkan oleh sang pendiri bangsa (funding father) kita yaitu Soekarno, tentang besarnya pengaruh pemuda/mahasiswa bila mereka bersatu, beliau pernah mengatakan dengan lantang "berikan saya sepuluh pemuda, maka saya akan bisa mengguncangkan dunia", itulah sejatinya prestasi yang akan diraih oleh pemuda/mahasiswa bila mana mereka menyatukan ide, pikiran, gagasan, dan bersama-sama melangkah melakukan perubahan untuk masyarakat, bangsa dan Negara tercinta ini, maka suatu perubahan yang nyata akan terlihat atau terpampang dengan jelas dari buah tangan atau karya pemuda/mahasiswa.

Peran mahasiswa dalam mensukseskan Pemilu 2014 sangat diharapkan, karena karakter mahasiswa yang sejatinya masih murni dari kendali atau pengaruh siapapun (independent). Mahasiswa harus berperan aktif membantu mengawas dan mengontrol berjalannya Pemilu agar terbebas dari hal-hal yang bertentangan dengan undang-undang.

Sejatinya kita semua harus menyatu dengan indah seperti halnya lidi-lidi yang berserakan dikumpulkan jadi satu, membentuk satu kekuatan yang utuh, yaitu kekuatan untuk membangun suatu masyarakat, bangsa dan Negara. Karena seberapa besarpun suatu persoalan kalau dikerjakan secara bersama maka akan 


\section{Terbit 10 Maret 2014}

"Kolektivitas Sukseskan Pemilihan Umum 2014"

terasa mudah, begitu juga sebaliknya, sesederhana apa pun suatu pekerjaan kalau dikerjakan sendirian akan terasa sulit adanya, seperti halnya sapu lidi, sapu lidi merupakan gabungan dari puluhan atau ratusan lidi, bila satu lidi ingin menyapu batu yang besarnya sebesar genggam tangan maka lidi tersebut tidak akan bisa menyapu batu itu, begitu juga sebaliknya, bila mana lidi-lidi tersebut digabungkan jadi satu dalam satu ikatan akan menjadi sapu lidi dan juga akan bisa menyapu batu yang besarnya sebesar genggaman tangan tersebut. Oleh karena itu, makna atau hasil yang didapat dari suatu kebersamaan itu akan bernilai tinggi adanya. Itulah sikap-sikap kolektifitas yang harus tertanam dalam hidup dan kehidupan dalam suatu masyarakat, bangsa dan Negara, yang mana bila kita ingin menggapai tujuan yang mulia sejatinya kita harus melaksakan tujuan tersebut secara bersamasama biar suatu persoalan sesulit apapun bisa dilakukan atau disa dipecahkan secara bersama-sama. Begitu juga apabila kita semua ingin mensukseskan Pemilu 2014 yang sebentar lagi akan diselenggarakan, kita harus bahu membahu membentuk satu kekuatan yang utuh untuk mensukseskannya.

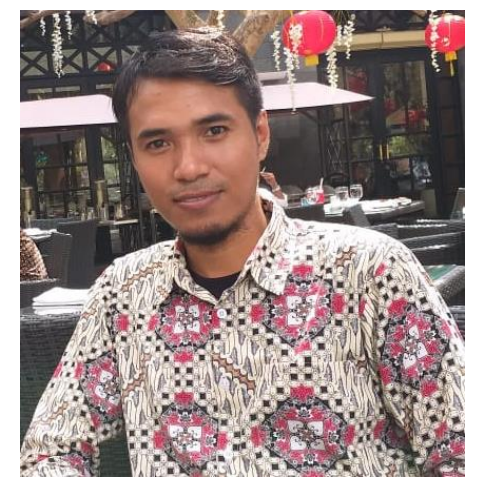

\section{Penulis: M. Jamil, S.H.}

Ketua Umum Pusat Studi Mahasiswa Pascasarjana (PUSMAJA) Mbojo-Yogyakarta Periode 2015-2017 | Ketua II Bagian Eksternal Dewan Pimpinan Cabang Perhimpunan Mahasiswa Hukum Indonesia Daerah Istimewa Yogyakarta (DPC PERMAHI DIY) Periode 2012-2014

\section{Ful Sumber Tulisan:}

M. Jamil, "Kolektivitas Sukseskan Pemilihan Umum 2014”, dimuat di https://www.fimny.or.id/2014/03/kolektivitas-sukseskan-pemilihan-umum.html, pada 10 Maret 2014. 